\title{
Pelagic seabirds and trawl-fisheries in the southern Benguela Current region
}

\author{
R. W. Abrams \\ FitzPatrick Institute, University of Cape Town, Rondebosch 7700, South Africa
}

\begin{abstract}
Counts of seabirds attending stern-trawlers in the southern Benguela Current region are analysed according to seasonal changes in species richness, Shannon-Wiener diversity index, mean abundance, and mean biomass at 540 observation stations. Patterns of occurrence of species in 4 foodtype and 6 feeding-method groups are identified. These patterns are compared with the composition of the avifauna predating large-scale, commercial mid-water and demersal trawl-fisheries in the Benguela region.
\end{abstract}

\section{INTRODUCTION}

Certain large-scale fishing activities, especially bottom and mid-water stern-trawling, provide a reliable supply of food for seabirds, including some items not naturally available to them (Watson, 1981). The degree to which this ready food source affects the overall ecology of seabirds in the Southern Ocean is unclear (Croxall, in press).

This paper describes the species composition, abundance and biomass of pelagic seabird assemblages attending trawlers in the southern sector of the Benguela Current region which is a major fishing ground for trawlers. The modern situaton is compared with information gathered in the same area about $30 \mathrm{yr}$ ago, prior to the development of a large-scale fishery (Abrams and Griffiths, 1981), in order to assess the potential influence of fisheries for changing the ecology of seabirds.

\section{STUDY AREA AND METHODS}

South African trawlers operate consistently in an area bounded by Latitudes $32^{\circ}$ and $35^{\circ} \mathrm{S}$ and between 90 and $150 \mathrm{~km}$ offshore, aligned roughly along the continental shelf edge, over depths between 300 and $500 \mathrm{~m}$ (Fig. 1). The targets of the fishery are bottom fish, chiefly hake (Merluccius spp.), and the catch is gutted throughout the afternoon. Ornithologists on board trawlers recorded numbers of seabirds from 1977 to 1980 . Counts of individual seabirds, crossing an imaginary line perpendicular to the ship's beam, were made according to the 10-min observation method (Griffiths, 1981). Counts of seabirds were recorded during all daylight hours on at least $6 \mathrm{~d}$ in each mo (cruise dates within each mo were selected at random), except April and October. Counts at $60 \%$ of the total number $(n=540)$ of observation stations were made before noon, preceding the first hauling of trawl-nets.

Computer-assisted correlation analyses of log-transformed data were carried out to assess patterns of cooccurrence of bird species richness (BSR, number of species), Shannon-Wiener index (Shannon and Weaver, 1963, $\mathrm{BSD}=H=-\Sigma$ pi. log. Pi, where $p i=$ proportion of the ith species in the community), abundance (mean number of birds) and mean biomass (total live-weight of birds) with each of 4 provisional principal food-type groups (see Appendix).

\section{RESULTS}

\section{Seabirds attending trawlers}

On average, 6 species attended a single trawler during the austral winter when seabird abundance and biomass were highest (Figs. 2 and 3). Although BSR and BSD varied seasonally, consistently diverse seabird assemblages attended trawlers throughout the year (Fig. 2)

The seabird assemblages were dominated generally, and especially in winter, by species which normally prey on cephalopods and which obtain their food on 


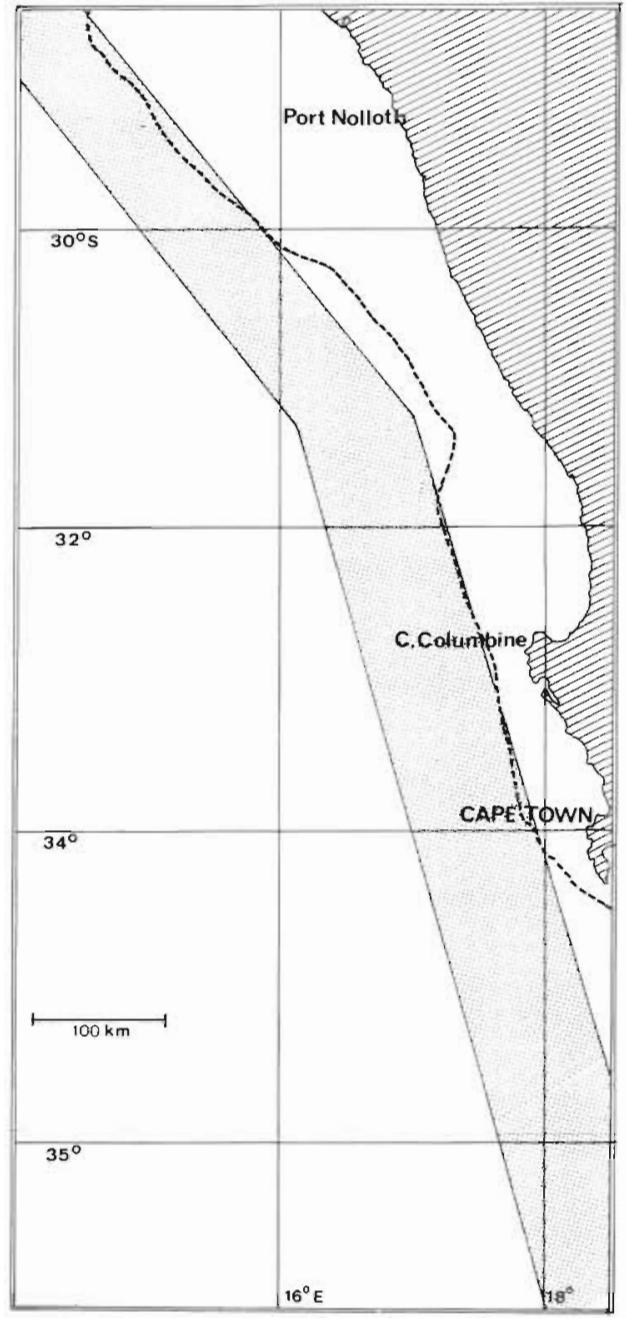

Fig 1. Southern sector of Benguela Current region. Broken line traces edge of continental shelf; stıppling represents area in which stern trawlers operated from 1977 to 1980

the surface $(r=0.999, p<0.001)$ of the sea (Table 1 , Fig. 4). The winter peaks were owed primarily to an influx of blackbrowed albatrosses Diomedea melanophris and whitechinned petrels Procellaria aequinoctialis from their breeding grounds in the Southern Ocean (Abrams and Griffiths, 1981). Together, these 2 species accounted for a mean of $400(\mathrm{SD}= \pm 700$, $\mathrm{n}=540$ ) birds per observation station, or $89 \%$ of the mean total number of individuals at a trawler in winter, which explains the negative correlation between cephalopod-eaters and BSD (Table 1). The departure of these seasonal visitors in spring resulted in an increased proportion of observations of locally breeding species. Fish-eating species (plunge, and pursuit plunge/dive feeders: $r=0.985,0.606$ respectively, both values $\mathrm{p}<0.001$, accounted for 1 to $23 \%$ of all individual birds recorded at trawlers (Fig. 5). Plankton-eating species and those whose diets are mixed (species not classifiable as predominantly plankton-, cephalopod- or fish-eaters), were not particularly abundant (Table 1); their abundances peaked in July and the spring, respectively (Fig. 6). The January peak was due mainly to gulls (Larus spp.; see Appendix) which made up $75 \%$ of all individual birds attending trawlers in that month

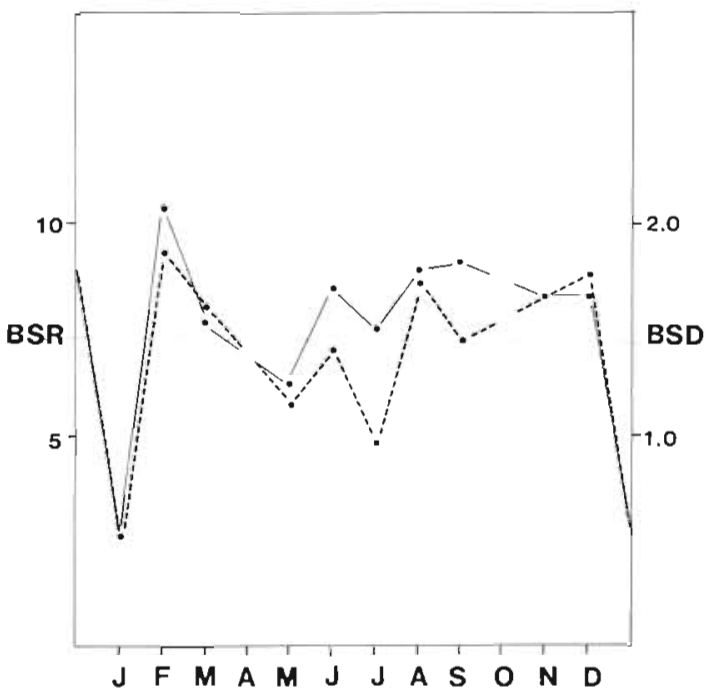

Fig. 2 Mean monthly species richness (BSR, continuous line) and diversity ( $B S D$, dashed line) per observation station of seabird assemblages attending stern trawlers, in the southern sector of the Benguela Current region (1977 to 1980). Mean BSR and BSD vary significantly by month (ANOVA $_{9.530}=289, \mathrm{P}<0.001$ and $\mathrm{F}_{9.530}=72.2, \mathrm{P}<0.001$. respectively)

Table 1. Coefficients of correlation ( $r$ ) between mean bırd species rıchness (BSR), mean bird species diversity (BSD), mean abundance (numbers of individuals) and mean biomass (live weight) of seabirds, in 4 food-type categories, attending stern trawlers in the southern Benguela Current regıon foom 1977 to 1980 . Mean values based on data from 540 observation stations

\begin{tabular}{lcccrr|}
\hline Food type & BSR & BSD & Abundance & Biomass $(\mathrm{kg})$ & \multicolumn{1}{c|}{ Mean } \\
\hline Plankton & 0486 & 0.415 & 0.145 & 0.134 & 9.13 \\
Cephalopods & 0.387 & -0.190 & 0971 & 0.975 & 739.83 \\
Fish & 0.545 & 0.414 & 0.426 & 0.421 & 17.54 \\
Mixed & 0461 & 0276 & 0.326 & 1578.77 \\
Mean & 8.06 & 1.39 & 830.27 & 150 \\
\hline
\end{tabular}




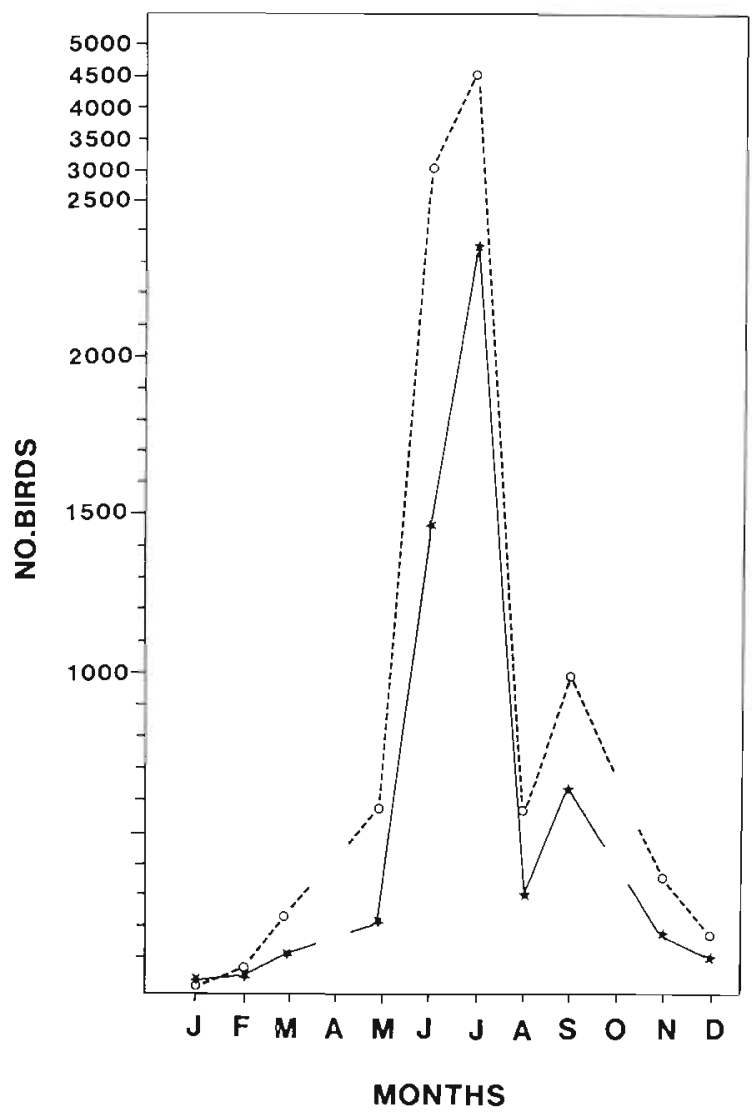

Fig. 3. Mean monthly abundance (numbers of individuals, continuous line) and biomass (dashed line) per observation station of seabird assemblages attending stern trawlers in the southern sector of the Benguela Current region during $1977-1980$

Absolute abundance and density of birds could not always be determined, because, at times, extra-large numbers of birds (as many as 7000 at an observation station) necessitated estimates being made. Nevertheless, between 500 and 2000 birds usually attended a single trawler; the mean abundance of birds within view of the observer increased from 408 before noon to 1468 in the afternoon when nets were hauled or fish were cleaned (Table 2). At these times, offal, dead and live fish were taken opportunistically by the birds. After the feeding frenzies associated with these activities subsided, the birds gathered in rafts of mixed species dispersed over a wide area near the trawlers, in which they apparently remained until the next day.

\section{Changes in the seabird community}

During the 1950 's, prior to large-scale stern-trawling in the southern Benguela region, the numbers of seabirds attracted to an oceanographic research vessel were recorded (Abrams and Griffiths, 1981). Birds

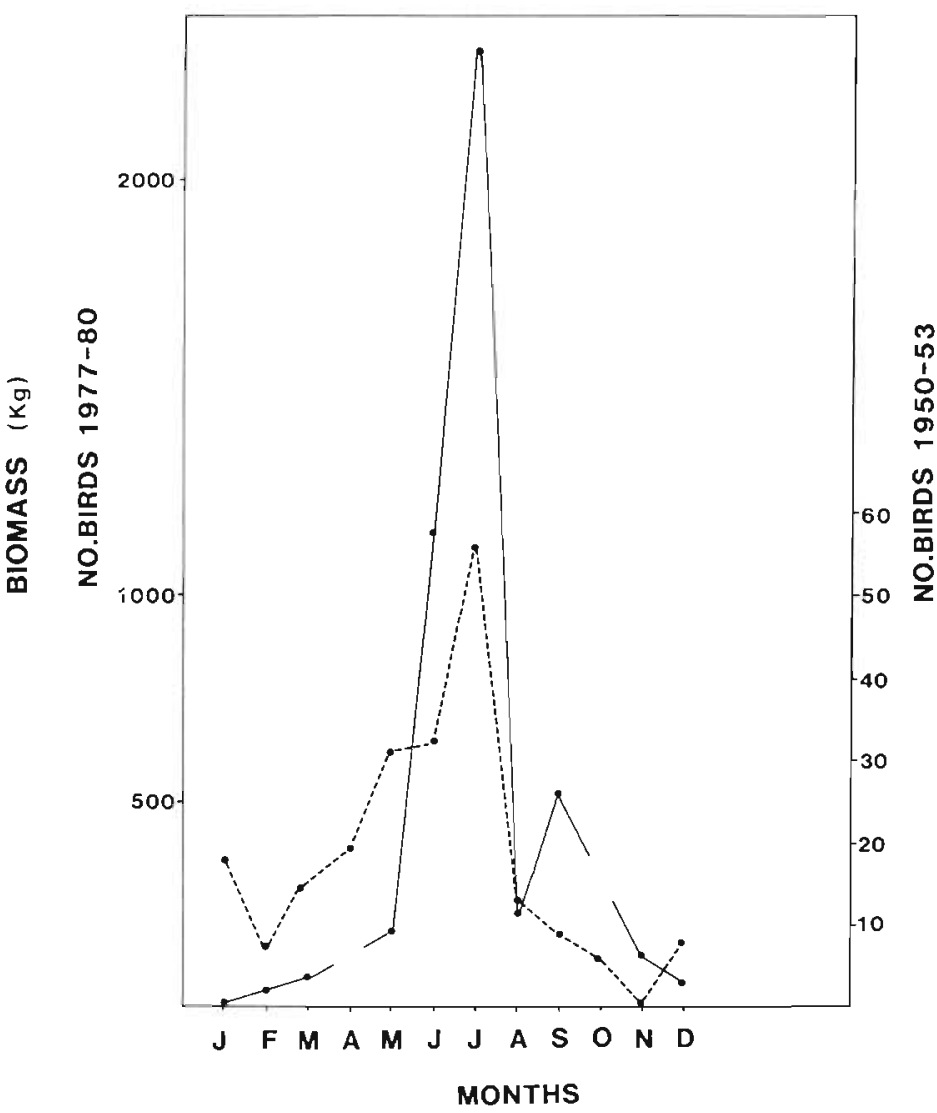

Fig. 4. Mean monthly abundance (number of individuals) per observation station of all cephalopod eaters in seabird assemblages attending stern trawlers from 1977 to 1980 (continuous line) and oceanographic research vessels 1950 to 1953 (dashed line) in the southern sector of the Benguela Current region

attracted to ships, while foraging, can be expected to approach either fishing or non-fishing vessels, but subsequent reinforcement of the behaviour, or a tendency of the birds to linger at a particular vessel, will depend on the type of vessel involved (Wahl and Heinemann, 1979). Many species in the Benguela region are

Table 2. Comparison of mean abundance (numbers of individuals) of seabirds, according to 4 food-type categories, attending stern trawlers in the southern sector of the Benguela Current region in relation to time of day. Difference between times established by Student's $t$-test

\begin{tabular}{|lrrr|}
\hline Food-type & \multicolumn{1}{c}{$\begin{array}{c}\text { Sunrise } \\
\text { to noon }\end{array}$} & \multicolumn{1}{c|}{$\begin{array}{c}\text { Noon } \\
\text { to sunset }\end{array}$} & t-test \\
\hline Plankton & $7.2 \pm 16.1$ & $12.0 \pm 26.3$ & $\mathrm{p}<0.02$ \\
Cephalopods & $356.7 \pm 586.9$ & $1318.9 \pm 1775.0$ & $\mathrm{p}<0.001$ \\
Fish & $34.3 \pm 121.1$ & $107.8 \pm 295.3$ & $\mathrm{p}<0.001$ \\
Mixed & $10.0 \pm 13.8$ & $29.6 \pm 925.0$ & $\mathrm{p}<0.01$ \\
Total & $408.2 \pm 605.5$ & $1468.4 \pm 1894.8$ & $\mathrm{p}<0.001$ \\
\hline
\end{tabular}


attracted to ships. Thus, in both the 1950's and the modern period the numbers of species and individual birds attending vessels normally increased to a peak in winter, after a trough in summer (Table 3 , Figs. 4 and 5). However, species richness (BSR) averaged $42 \%$ higher in assemblages at trawlers than at oceano-

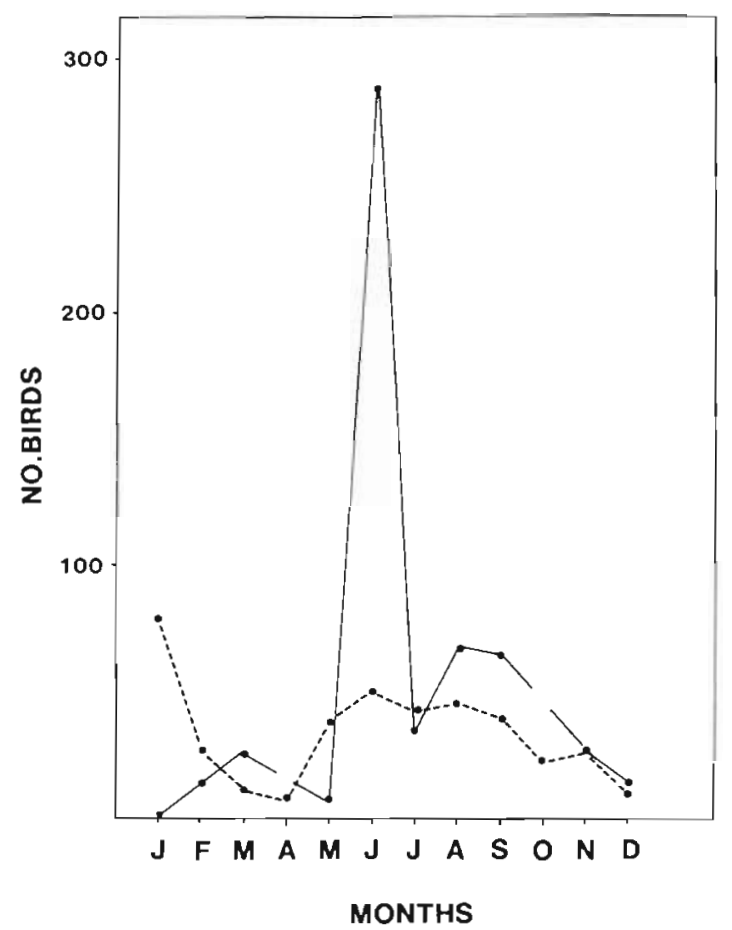

Fig. 5. Mean monthly abundance (number of individuals) per observation station of fish-eating species in seabird assemblages attending stern trawlers from 1977 to 1980 (continuous line) and oceanographic research vessels 1950 to 1953 (dashed line) in the southen sector of the Benguela Current region

Table 3. Relative increase in bird species richness (BSR), abundance (numbers of individuals) and biomass (live weight) between 1950 and 53 (data from oceanographic research vessels) and 1977 and 80 (data from stern-trawlers) in the southern Benguela Current region. Levels of significance by Student's t-test

\begin{tabular}{|ccccc|}
\hline Parameter & Summer & Fall & Winter & Spring \\
\hline BSR & & & & \\
$\%$ & 52.9 & 11.7 & 30.3 & 71.8 \\
$\mathrm{df}$ & 314 & 366 & 467 & 391 \\
$\mathrm{p}<$ & 0.001 & 0.001 & 0.001 & 0.001 \\
Abundance & & & & \\
$\%$ & 68.2 & 266.4 & 1171.0 & 1004.8 \\
$\mathrm{df}$ & 314 & 366 & 467 & 391 \\
$\mathrm{p}<$ & 0.01 & 0.001 & 0.001 & 0.001 \\
Biomass & & & & \\
$\%$ & 20.7 & 360.6 & 1254.3 & 755.9 \\
$\mathrm{df}$ & 314 & 366 & 467 & 391 \\
$\mathrm{p}<$ & 0.001 & 0.001 & 0.001 & 0.001 \\
\hline
\end{tabular}

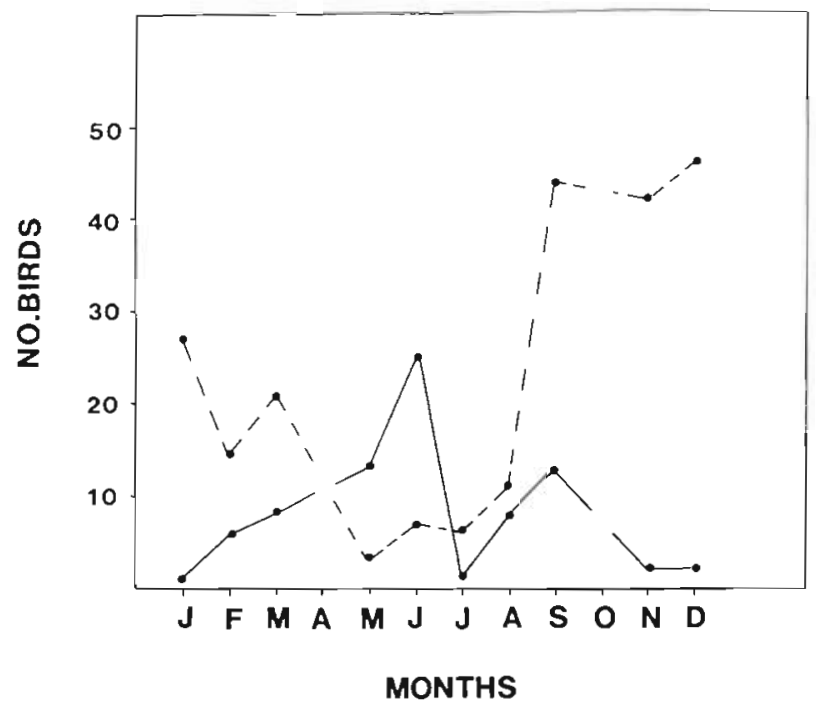

Fig. 6. Mean monthly abundance (numbers of individuals) per observation station of all plankton-eaters (continuous line) and species in the mixed food-type category (dashed line) in seabird assemblages attending stern trawlers in the southern sector of the Benguela Current region

graphic vessels in the 1950's (Table 3). The most salient feature of this tentative comparison appears to be the modern increase in abundance, particularly of cephalopod-eating Procellariiformes, amounting to a 12 -fold increase in biomass per trawler-based observation in peak seasons (Fig. 4, Table 3). It seems that albatrosses and petrels have refocused their diets to include more fish, but without changing their surfaceseizing/scavenging feeding behaviour.

\section{DISCUSSION}

The information reported here suggests that in the last $30 \mathrm{yr}$ the abundance of seabirds, notably certain seasonal visitors from the Southern Ocean, and particularly the blackbrowed albatross and the whitechinned petrel, has increased in the southern sector of the Benguela Current region. If there has not been an increase in absolute abundance of these and other species in the Benguela region, then there has been a significant change in their local distribution. These birds have learnt to exploit an abundant and readily available source of food produced by man's fishing activities, and have, temporarily at least, refocused their diets in the process. If a large enough proportion of a species' world population consistently frequents, and comes to depend on, a particular area where it scavenges at fishing vessels, there is potential for modification of that species' global distribution, foraging behaviour, diet and survival, and ultimately its overall biological evolution. The blackbrowed albatross is 
Appendix. Principal food type, feeding method categories and body-weights of seabird species occurring at stern trawlers in the southern sector of the Benguela Current region (1977 to 1980). Principal food type and feeding-method classification are provisional and based on data in Ashmole (1971), Ainley (1977) and unpublished records from the FitzPatrick Institute which also maintains records of bird weights.

\begin{tabular}{|c|c|c|c|}
\hline Food type & Feeding method & Species & $\begin{array}{c}\text { Body weight } \\
(\mathrm{kg})\end{array}$ \\
\hline Plankton & $\begin{array}{l}\text { Dipping \& pattering } \\
\text { Dipping \& pattering } \\
\text { Pursuit plunging } \\
\text { Surface filtering } \\
\text { Surface seize/scavenge } \\
\text { Dipping \& patterning } \\
\text { Dipping \& pattering }\end{array}$ & $\begin{array}{l}\text { Oceanodroma leucorhoa, Leach's Stormpetrel } \\
\text { Oceanites oceanicus, Wilson's Stormpetrel } \\
\text { Puffinus assimilis, Little Shearwater } \\
\text { Pachyptila spp., Prion } \\
\text { Daption capense, Pintado Petrel } \\
\text { Hydrobates pelagicus, British Stormpetrel } \\
\text { Hydrobates spp., Stormpetrels }\end{array}$ & $\begin{array}{l}0.05 \\
0.04 \\
0.23 \\
0.15 \\
0.45 \\
0.35 \\
0.05\end{array}$ \\
\hline Cephalopods & $\begin{array}{l}\text { Surface seize/scavenge } \\
\text { Surface seize/scavenge } \\
\text { Surface seize/scavenge } \\
\text { Surface seize/scavenge } \\
\text { Surface seize/scavenge } \\
\text { Surface seize/scavenge } \\
\text { Surface seize/scavenge } \\
\text { Surface seize/scavenge } \\
\text { Surface seize/scavenge } \\
\text { Surface seize/scavenge } \\
\text { Surface seize/scavenge } \\
\text { Surface seize/scavenge }\end{array}$ & $\begin{array}{l}\text { Pterodroma macroptera, Greatwinged Petrel } \\
\text { Diomedea cauta, Shy Albatross } \\
\text { Diomedea chlororhynchos, Yellownosed Albatross } \\
\text { Diomedea melanophris, Blackbrowed Albatross } \\
\text { Procellaria cinerea, Brown Petrel } \\
\text { Procellaria aequinoctialis, Whitechinned Petrel } \\
\text { Pterodroma mollis, Softplumaged Petrel } \\
\text { Diomedea exulans, Wandering Albatross } \\
\text { Diomedea chrysostoma, Greyheaded Albatross } \\
\text { Pterodroma incerta, Atlantic Petrel } \\
\text { Phoebetria fusca, Sooty Albatross } \\
\text { Fulmarus glacialoides, Southern Fulmar }\end{array}$ & $\begin{array}{l}0.58 \\
4.10 \\
2.00 \\
3.50 \\
1.03 \\
1.21 \\
0.31 \\
8.60 \\
3.67 \\
0.52 \\
2.54 \\
0.76\end{array}$ \\
\hline Fish & $\begin{array}{l}\text { Surface seize/scavenge } \\
\text { Dipping \& pattering } \\
\text { Pursuit plunging } \\
\text { Pursuit plunging } \\
\text { Dipping \& pattering } \\
\text { Pursuit diving } \\
\text { Plunging } \\
\text { Pursuit diving } \\
\text { Dipping \& pattering } \\
\text { Dipping \& pattering }\end{array}$ & $\begin{array}{l}\text { Calonectris diomedea, Cory's Shearwater } \\
\text { Sterna vittata, Antarctic Tern } \\
\text { Puffinus gravis, Great Shearwater } \\
\text { Puffinus griseus, Sooty Shearwater } \\
\text { Sterna hirundo, Common Tern } \\
\text { Phalacrocorax capensis, Cape Cormorant } \\
\text { Morus capensis, Cape Gannet } \\
\text { Spheniscus demersus, Jackass Penguin } \\
\text { Sterna paradisaea, Arctic Tern } \\
\text { Sterna spp., Terns }\end{array}$ & $\begin{array}{l}0.96 \\
0.14 \\
0.95 \\
0.79 \\
0.10 \\
1.28 \\
2.69 \\
2.99 \\
0.13 \\
0.13\end{array}$ \\
\hline Mixed & $\begin{array}{l}\text { Piracy } \\
\text { Dipping \& pattering } \\
\text { Piracy } \\
\text { Piracy } \\
\text { Piracy } \\
\text { Piracy } \\
\text { Surface seize/scavenge } \\
\text { Surface seize/scavenge } \\
\text { Surface seize/scavenge }\end{array}$ & $\begin{array}{l}\text { Stercorarius longicaudus, Longtailed Skua } \\
\text { Larus hartlaubii, Hartlaub's Gull } \\
\text { Larus dominicanus, Kelp Gull } \\
\text { Stercorarius parasiticus, Arctic Skua } \\
\text { Stercorarius pomarinus, Pomarine Skua } \\
\text { Catharacta antarctica, Antarctic Skua } \\
\text { Larus sabini, Sabines gull } \\
\text { Macronectes halli, Northern Giant Petrel } \\
\text { Macronectes giganteus, Southern Giant Petrel }\end{array}$ & $\begin{array}{l}0.29 \\
0.30 \\
1.00 \\
0.53 \\
0.67 \\
1.63 \\
0.70 \\
4.86 \\
4.35\end{array}$ \\
\hline
\end{tabular}

very abundant in the southern Benguela trawling grounds, and it is conceivable that an entire population cohort has come to depend solely on this area during the austral winters. (According to Croxall, in press, the average life expectancy in the species is about $25 \mathrm{yr}$, with $40 \%$ of the population reaching $10 \mathrm{yr}$. Thus, the birds could experience both a behavioural and a food crisis, if the trawling industry ceases to operate.

Acknowledgements. This research was supported financially by the South African National Committee on Oceanographic Research. Sea Harvest Pty. Ltd., Saldanha Bay, provided generous assistance.

\section{LITERATURE CITED}

Abrams, R. W., Griffiths, A. M. (1981). Ecological structure of the pelagic seabird community in the Benguela Current region. Mar Ecol. Prog. Ser. 5: 269-277

Ainley, D. G. (1977). Feeding methods in seabirds: a comparison of polar and tropical nesting communities in the eastern Pacific Ocean. In: Llano, G. A. (ed.) Adaptations within Antarctic Ecosystems. Smithsonian Institute, Washington, D C., p. 669-685

Ashmole, H. P. (1971). Seabird ecology and the marine environment. In: Farner, D. S., King, A. (eds.) Avian biology (1). Academic Press, New York, p. 224-271

Croxall, J. P. (in press) Seabird ecology. In: Laws, R. H. (ed) Antarctic ecology

Griffiths, A. M. (1981). Biases in censuses of pelagic seabirds 
at sea in the Southern Ocean. In: Cooper, J. (ed.) Proc. Symp. Birds in the Sea and Shore, African Seabird Group, Cape Town, 1979

Shannon, C. E., Weaver, W. (1963). The mathematical theory of communication. University of Illinois Press, Urbana
Wahl, T R., Heinemann, D. (1979). Seabirds and fishing vessels: co-occurrence and attraction. Condor $81: 390-396$

Watson, P. S. (1981). Seabird observations from commercial trawlers in the Irish Sea. Br. Birds 74: 82-90

This paper was submitted to the editor; it was accepted for printing on July 28, 1982 